\title{
Public Libraries and Democratization in Three Developing Countries: Exploring the Role of Social Capital
}

\author{
Gabe Ignatow, Sarah M. Webb, Michelle \\ Poulin, Ramesh Parajuli, Peter Fleming, \\ Shika Batra, and Diptee Neupane
}

Dr. Gabe Ignatow, Assistant Professor, Department of Sociology, University of North Texas, Denton, Texas, USA

Email: ignatow@unt.edu

Sarah M. Webb, Doctoral Candidate, School of Information Studies, Syracuse University, Syracuse, New York, USA

Email: swebb01@syr.edu

Dr. Michelle Poulin, Assistant Professor, Department of Sociology, University of North

Texas, Denton, Texas, USA

Email: Michelle.Poulin@unt.edu

Ramesh Parajuli, Research Associate, Martin

Chautari, Kathmandu, Nepal

Email: rameshparajuli@gmail.com

Peter Fleming, Co-founder and Executive Director, Invest in Knowledge Initiative, Boston, USA

Email: pcfleming@gmail.com

Shika Batra, Doctoral Candidate, Department of Sociology, University of North Texas, Denton, Texas, USA

Email: shikha.bedi@unt.edu

Diptee Neupane, Doctoral Candidate, Department of Sociology, University of North Texas, Denton,

Texas, USA

Email: Diptee.Neupane@unt.edu

\section{Abstract}

Investments in public libraries in developing countries have been made based on the idea that libraries contribute to societal democratization. Yet scholarly understanding of the relationships between public libraries and democratization is sharply limited. In this article we review historical studies of national public library systems that cast doubt on widely held assumptions that a positive relationship necessarily pertains between the establishment of public libraries and democracy. Based on this historical review and on sociological theories of social capital (e.g. Bourdieu 1986), we develop a theoretical framework intended to facilitate systematic investigation of the contributions public libraries may make to democracy. Using comparative historical and ethnographic methods, we analyze the relationship between public libraries and democratic systems of government in Namibia, Nepal, and Malawi, and find that in all three cases public libraries were established mainly during democratic regimes. However, they were not necessarily established by democratically elected governments directly, but rather because democratic regimes proved to be relatively open to the influence of diasporas and global civil society. We only find evidence of public libraries contributing to societal democratization, as we conceptualize the process, in Nepal and to a limited degree Namibia - countries that lack a long-established, empowered elite class. We discuss possible implications of our analysis for library scholarship and its relations to theories of development.

\section{Introduction}

For decades, international governmental and nongovernmental organizations such as UNESCO and the International Federation of Library Associations (IFLA) have invested in public libraries in developing countries based on the idea that libraries contribute to democratization and national development. The UNESCO Public Library Manifesto, first published in 1947, states that "fundamental human values" can only be attained in a democratic society, and that democratic "participation and the development of democracy depend on ... free and unlimited access to knowledge, thought, culture and information" (UNESCO 1994). Similar principles are espoused by IFLA. The idea that libraries are inherently democratic institutions is rooted in the Enlightenment tradition of educational philosophy (Buschman 2007), a tenet of which is that, by public education and public libraries, "a wholesome capable citizenry would be fully schooled in the conduct of 
democratic life" (Ditzion 1947, 74). Public libraries are understood to both enlighten and empower the public: "Public libraries belong to ... the "network of engagement' that anchors people to communities and fosters a sense of fellowship, civic participation, and democratic living. [They] represent a civilized and civilizing community institution that equalizes and enlarges access to knowledge" (Dain 1996, 72, quoted in Buschman 2007, 1484). Democracy is widely thought to be both a cause and an effect of public libraries. It is thought to be a cause of public libraries because it is assumed that citizens in a democratic political system, guided by their reason, recognize the advantages conferred by libraries and freely choose to establish more and better public libraries. Democracy is thought to be an effect of public libraries as well: public libraries are seen as "arsenals of a democratic culture" (Ditzion 1947) that equip citizens to "exercise their democratic rights and to play an active role in society" (UNESCO 1994).

Yet while both practitioners and scholars (e.g. Lievrouw 1994; Kranich 2001; McCook 2001, 2004) argue that libraries are basically democratic institutions, scholarly understanding of the relationships between democratic development and public libraries is sharply limited. There have been very few "specific, nuanced historical examinations of libraries and democracy" (Buschman 2007, 1486), and almost no systematic comparative historical studies (cf. Ignatow 2009, 2011). As a consequence, it is not known whether developing countries with democratically elected governments establish more public libraries than do those with non-democratic governments. Nor is it known whether developing countries that build public libraries tend to become more democratic in the long run.

In this article we propose a new theoretical framework for thinking about the relationship between public libraries and democratization in developing countries, one that is intended to facilitate systematic comparative research. We first review historical studies of national public library systems that cast doubt on widely held assumptions that a positive relationship necessarily pertains between the establishment of public libraries and the development of democratic systems of governance. Next we propose a theoretical framework based on theories of social capital (Bourdieu 1984, 1986; Putnam 2000) that is intended to facilitate systematic investigation of how public libraries may promote democratization.
In brief, our argument is that in order to meaningfully contribute to democracy, public libraries must generate and distribute cultural, social, and economic capital to non-elites (we provide working definitions of these terms later in the article). Using our theoretical framework to analyze the historical relationships between public libraries and democratic systems of government in Namibia, Nepal, and Malawi, we find that in all three cases public libraries were established mainly during periods of democratic rule. However, they were not necessarily established by these democratically elected regimes, but rather because democratically elected governments proved to be relatively open to outside influence from diasporas and global civil society. However, we only find evidence that public libraries contribute to societal democratization, as we conceptualize the process, in Nepal and, to a limited degree, Namibia - countries that lack an established elite class. In the conclusions we discuss possible implications of our analysis for both development theory and library research.

\section{Democratization as a contributor to library system development}

There is not much evidence of public libraries in developing countries being established as the end result of democratic political processes. And there is much evidence to the contrary (e.g. Ignatow 2009). In a large number of cases of developing countries investing heavily in their public libraries, these investments have occurred during periods of either colonial administration or of post-revolutionary elite-led nation-building; almost always been accompanied by heavy censorship; and been carried out expressly for purposes of social control. For example, the development of working-class subscription libraries in Scotland was promoted by paternalistic lead-mining companies (Jackaman 1980) whose aim was to create well-disciplined miner communities (Crawford 1997). Harris (1973, 1986) pioneered a revisionist turn in American library history by detailing how the major benefactors of America's earliest public libraries were conservative elites who supported libraries that were authoritarian and elitist. Elites hoped that the public library in nineteenth century America would serve as a stabilizing force during a period of mass immigration and high levels of social unrest and urban crime (see also Du Mont 1977). 
During the Cold War, the U.S.A. and U.S.S.R. fought a "cultural Cold War" (Saunders 2006) in nonaligned nations, with the Soviets building libraries in these nations, donating massive numbers of books, and training foreign library professionals in Soviet library programs (Andersen, Friis-Hansen, and Kajberg 1985; Richards 1999). The United States responded by providing funding for libraries and information centers in the third world through the United States Information Agency (Elder 1968; Bogart 1976; Snow 1998). These funds almost entirely evaporated with the end of the Cold War (Nye 2004). South Korea's public library system was built up first by Christian missionaries, then Japanese colonial occupiers who used them for propaganda purposes in an effort to stamp out Korean national identity, and later by American agencies during the Cold War (Chang 2000). Libraries were established under similar conditions in Kenya (Rosenberg 1993; Olden 1995), the Caucasus and Crimea (Jersild and Melkadze 2002), and Indonesia (Fitzpatrick 2008). Historical cases such as these cast doubt on widely held assumptions, informed by Enlightenment philosophy, that a positive relationship necessarily pertains between the establishment of public libraries and the development of democratic systems of governance. History thus provides ample evidence of public libraries being established in large numbers by a range of types of political regimes, including non-democratic regimes, for many different reasons.

\section{Contributions of public libraries to democratization}

Although public libraries are often claimed to contribute to democratic development, we are aware of no systematically collected evidence that shows that public libraries have contributed to democratization in developing countries. In addition, some problems with the idea that libraries necessarily encourage democracy in developing countries are apparent. First, in countries with high rates of illiteracy, public libraries might be co-opted by a literate upper class. Despite their status as public institutions, they might become, effectively, exclusive and undemocratic (Sturges and Neill 1998). And second, through official censorship, libraries might encourage citizen acquiescence and conformity rather than participatory democracy (Steig 1992). This latter possibility is widely acknowledged, and the UNESCO Public Li- brary Manifesto, UNESCO library programs, and other efforts by IGOs and INGOs in developing countries accordingly take pains to limit government censorship.

\section{A social capital model of public library development}

The historical record as described above shows that public libraries are not necessarily a cause or an effect of democratic governance, but does leave open the possibility that, under certain social conditions, libraries may promote democratization. To consider this possibility, we develop new conceptual tools to analyze the relations between public libraries and democratic systems of government. In attempting to develop such tools, we begin with a set of theoretical concepts developed by sociologists including, inter alia, Pierre Bourdieu (1984, 1986) and Robert Putnam (2000). We do not claim to do justice to the body of work of either theorist or to the large social science literature on social capital. Instead we use a few of the concepts these and other sociologists have developed - of cultural, social, and economic capital - in order to analyze the relationship between public libraries and democracy in three developing countries.

With Bourdieu, we conceptualize cultural institutions such as libraries as products of a multidimensional arena or "field" of social conflict. Bourdieu views all social actors as striving to acquire capital, which he defines as anything that is scarce and valuable, and that confers social distinction on its holder. Bourdieu identifies three categories of capital: cultural, social [1], and economic. In brief, cultural capital refers to forms of cultural knowledge that are scarce and valuable, and therefore exclusive, such as private education, foreign travel, and elite pastimes. Social capital refers to the size and status of an individual's social network. And economic capital refers to financial wealth. The three forms of capital do not exist in a zero-sum relationship, but for Bourdieu social action can be modeled as individuals transforming one form of capital into another over the life course, as social actors gain cultural capital (exclusive cultural knowledge) from their friendship and family networks, use that capital to forge new social ties, invest their economic capital in valuable forms of cultural capital, and so on. 
Bourdieu's theoretical framework leads us to view libraries as cultural institutions that are established, promoted, and funded by groups of elites with group-specific interests and worldviews: elites are likely to invest in public libraries if their main beneficiaries are likely to be their children and other members of their own social class. An implication of this approach is that public libraries contribute to democracy in only a relatively narrow range of cases. From a Bourdieuian perspective, if they are to meaningfully contribute to democracy, public libraries must generate and distribute scarce, and therefore valuable, cultural capital to non-elites (Bourdieu 1986). Following Bourdieu's logic, in the context of public libraries we can provisionally define cultural capital as access to libraries and their resources - librarians and library materials such as books, newspapers, magazines, audiovisual materials, and Internet access. But not all library materials are equally valuable. A practical shorthand way of determining the value of library materials qua cultural capital would be to examine if libraries are available to all and if their materials are the same as those available in private schools" libraries, public libraries used exclusively by elites, and other private or otherwise exclusive cultural institutions. For example, Hall (2007) describes the differences between the libraries in a poor neighborhood and a wealthy one. Hall does not use Bourdieu's terms to describe the differences between the libraries, but she does make clear that the library in the wealthy neighborhood provides access to more and better of everything in the library. Children living near the library in the wealthy neighborhood have access through the library to more cultural capital than the children in the poor neighborhood (Hall 2007).

The concept of social capital has been developed to perhaps the greatest effect by Putnam (2000), and it is his conceptualization that we find most useful here. Putnam defines social capital in terms of the size and strength of family and friendship networks, and argues that social capital is a key determinant of an individual's life outcomes such as school attrition, academic performance, and intellectual development. Putnam and his colleagues further argue that social capital in the form of associational involvement and participatory behavior in a community is critical for functioning democracies (e.g. Putnam, Leonardi, and Nanetti 1993). Public libraries can be conceptualized as generating social capital, in Put- nam's terms, insofar as they offer adequate physical space for social networking and associational activities (see Vårheim 2009).

Finally, while public libraries do not generate or distribute money directly to the public, they can potentially make publicly available valuable business and labor market information resources. For example, many libraries subscribe to business magazines and employer databases, and provide access to the Internet or classified advertisements through the local newspaper. For our purposes, such resources can be considered a form of economic capital.

Both Bourdieu and Putnam contend that the acquisition of sufficient social capital, in all its forms, is a prerequisite for meaningful participation in democracy. Absent sufficient capital, social actors become disengaged from civic life (Putnam 2000), and are susceptible to "symbolic violence" by social elites (Bourdieu 2001). Symbolic violence is defined by Bourdieu as a "gentle violence," imperceptible to its victims, "exerted for the most part through the purely symbolic channels of communication and cognition" (Bourdieu 2001, 1-2). Examples of symbolic violence include insecurity with regard to one's appearance, dialect, accent, tastes, or lack of cultural knowledge. Without sufficient capital, it is prohibitively difficult for citizens to form grass roots social organizations (Bourdieu 1999). Public libraries thus promote democracy if they generate and distribute cultural, social, and economic capital, because generating and distributing such capital empowers its recipients to pursue their self- and group interests. But it is clear that the use of public libraries for the generation and distribution of cultural, social, or economic capital requires a sustained commitment of resources by the state or nongovernmental organizations.

\section{Identifying public libraries' contributions to democratization}

Below we present four propositions, based mainly on the social capital theoretical framework sketched above, that address public libraries' possible contributions to societal democratization. In terms of our theoretical framework, in order to contribute to democratization they must provide valuable cultural capital to non-elites in the form of unrestricted access to libraries and their materials similar in value to those found in nearby elite institutions. Libraries 
Table 1. Recent public library statistics for Namibia, Malawi, and Nepal.*

\begin{tabular}{lccc}
\hline & Namibia & Malawi & Nepal \\
\hline $\begin{array}{l}\text { Population* } \\
\text { (2008, in millions) }\end{array}$ & 2.1 & 13.9 & 29.5 \\
$\begin{array}{l}\text { GDP per capita } \\
(2005, \text { PPP)* }\end{array}$ & US $\$ 7,586$ & US $\$ 667$ & US $\$ 1,550$ \\
$\begin{array}{l}\text { Civil and Political Liberties } \\
\text { (Freedom House)** }\end{array}$ & 4.5 & 4 & 3.5 \\
$\begin{array}{l}\text { Gini Coefficient* } \\
\text { Public Libraries }\end{array}$ & 74.3 & 39 & 47.2 \\
Public Library Volumes & 60 & 16 large libraries & $600+* * *$ \\
\end{tabular}

* Demographic and economic statistics are based on the most recent available data from the World Development Indicators database (World Bank 2005). The Gini index is a widely used measure of national income inequality.

** Civil and political liberties is an index ranging from 7 (high levels of liberties) to 1 (low levels of liberties) that represents the average of two indicators--civil liberties and political liberties--collected by Freedom House based on country case studies (Freedom House 2001).

*** 28 state central libraries, 451 district libraries, 501 taluka libraries and 28,820 rural libraries (Dogra and Gulati 2006).

**** Estimate based on data from visits to 11 libraries, and estimation of the collections of the country's other libraries.

must be accessible to large numbers of people at a time, allowing for the spontaneous formation of new social ties and the generation of social capital. And they must offer valuable business and labor market information that can generate economic capital. To meaningfully contribute to democratization, as we have conceptualized the process, public libraries in developing countries must meet all or at least some of these criteria, though in this study we do not yet provide metrics for measuring these forms of capital, or thresholds that must be exceeded for each for libraries to be considered to be contributing to democratization. Still, a social capital theoretical framework can at least potentially accommodate different metrics for particular cases on an ad hoc basis.

Our first proposition is derived from arguments made by scholars (Lievrouw 1994; Kranich 2001; McCook 2001, 2004) and practitioners alike (UNESCO 1994) that there are strong positive relationships between democratic systems of government and the establishment and expansion of public library systems.

- Proposition 1. More democratic developing countries invest more in public libraries than do less democratic ones, ceteris paribus

- Proposition 1a. For a given country, public library systems expand more during periods of democratic government than during periods of non-democratic government.
- Proposition 1b. Public libraries in developing countries are the end result of public, deliberative, democratic political processes.

Our next three propositions are all based on social capital theory, as outlined above.

- Proposition 2. Public libraries in developing countries generate and distribute valuable cultural capital. (Their collections are of comparable quality to those available in private and forprofit institutions.)

- Proposition 3. Public libraries in developing countries generate and distribute valuable social capital. (They provide public spaces for social networking and meetings.)

- Proposition 4. Public libraries in developing countries generate and distribute valuable economic capital. (They provide informational resources for small businesses and job-seekers.)

\section{Public libraries in Namibia, Nepal, and Malawi}

In what follows we provide an overview of the history of public library development in Namibia, Nepal, and Malawi. We chose these countries for our analysis mainly because of their similar levels of economic and human development, and because all three have experienced democratic transitions since the 1960s, and periods of more democratic, and more 
authoritarian, rule post-independence. National-level economic, social, and library statistics for each country are presented in Table 1.

\section{Methodology}

The methodology for our analysis of the library systems of three nations is twofold. First, we employ methods of comparative historical sociology (Skocpol and Somers 1980) to analyze the chronology (Büthe 2002) of the development of each country's national public library system in relation to changes in regime type. Next, for each country we employ first-hand ethnographic methods to document contemporary conditions within public libraries in these three countries in light of our four propositions.

\section{Namibia}

The origins of Namibia's public libraries lie in the early twentieth century, when the libraries were built in the centers of the larger towns for use by White colonialists and settlers (Tötemeyer and Stander 1990). These libraries contained mostly fiction books, and required payment of an annual fee in order to borrow materials. Blacks and members of other groups who were prohibited from using libraries recognized that they were part of an exclusive, elite lifestyle. In 1985, a change in national law nominally allowed use of the library by all, but the new law was little publicized, and in practice library services were little changed. After Namibia gained independence from South Africa in 1990 and overturned the country's Apartheid laws, libraries did gradually democratize their services.

In 1997, a policy document on Namibian libraries suggested that libraries could promote national development. The report considered all types of libraries, but described public libraries as "the critical interface between communities and the nation's information services. Such libraries serve as community learning centers, cultural centers, information dissemination centers and centers for recreational reading, which enable newly literate persons to consolidate their reading skills" (Harper 1997). The report had an impact in the form of a national Library Act that was passed in 2000. The Library Act clarified the administrative and funding structure for all of the government-run libraries, which are today administered from a directorate in the Ministry of
Education, and their funding is overseen by a national council. The public libraries are a division of this structure called the Community Library Service. Public libraries are built or maintained partly by the municipality in which they reside and partly by the Ministry of Education. The town provides the building and the maintenance of the building, while the Ministry of Education provides staff and materials through the Community Library Services.

When Namibia gained independence from South Africa in 1990, there were 22 public libraries in the country; as of 2010 there are 60 . As the system expanded over this period, government funding for the libraries proved inadequate to the task of meeting public demand for books. As a consequence, the national Community Library Service has turned to Book Aid International [2], an International Non-Governmental Organisation (INGO) that supplies books to developing countries. While Book Aid Internation$a l$ is the most prominent international supporter of the libraries, other INGOs are involved as well. For example, the 1997 national report was funded by the Swedish International Development Agency (SIDA). The government's increasing reliance on global civil society has shifted some of the responsibility for creating and maintaining libraries from the government to the global community. An examination of the public libraries of Windhoek, Namibia's capital city, further illuminates these patterns.

\section{Windhoek Public Libraries}

Windhoek Public Library was built in the 1920s to serve the white population, and is the only public library serving the wealthy areas of the city. Windhoek has always been segregated, and in the late 1950s this segregation was more rigorously enforced with the removal of most blacks from their homes and the creation of Katutura, a large black township to the north of the city. A library was built in Katutura for those blacks who were working towards matriculation. This library was not built by the government, but rather by the Lions Club [3] and was a charity library designed to support formal education rather than pleasure reading. Note that this library had a different collection of materials, and therefore did not allow access to the cultural capital available from the public library open to Whites.

Today Katutura has three libraries, all primarily oriented to supporting education. The first library in 
the city was the library built by the Lions Club. Until 2009 it was administered by the Rössing Foundation, a local non-profit group. This library is in the heart of Katutura, next to a bustling mall. The Windhoek municipality, through a sister city arrangement with the Finnish city of Vantaa, built a second library, the Greenwell Matongo Community Library, on the outskirts of Katutura. The third library is in the Maxiulili Community Centre on the further reaches of Katutura in an area where all housing is informal corrugated iron shacks. Microsoft and CISP [4], an Italian NGO, contributed to building this library. All three of these libraries are also supported by the national government through the Community Library Services. Their collections are new, and mainly support education. They all have some fiction materials, including books by Namibian authors and South African authors, but the bulk of the collection is in education materials. The Windhoek Public Library still has the large fiction collection it built up through the years. It now has more materials to support education, as these are the materials that the Community Library Service buys for all of the libraries. To read the culture of Namibia and South Africa and to share the cultural heritage of the White population (which is still elite), one has to read the materials in the Windhoek Public Library.

Use of Namibian public libraries is free, but payment of an annual membership fee is required to borrow books to bring home. The fee is about .85 USD for adults. Fees for public education are a common and accepted practice as well. Many Namibians from the poor areas of Katutura use the public libraries to improve their school performance; they believe that studying in the library will help them to succeed in school, which will help them succeed in life and achieve an elite status. As one Katutura child succinctly put it, "to be someone you need school." But success in school does not necessarily provide entré into elite society, as in Namibia, social ties are seen as crucial for getting a job.

Regarding Proposition 1a (democracy), the answer is yes: most of the country's public libraries were established in the democratic era after apartheid rule ended. Forty new libraries have been established since independence, and the number of libraries in the country has almost tripled in size. Regarding Proposition 1b, it appears from the history of the Windhoek libraries that INGO interest can lead to the building of libraries without much democratic deliberation.

Regarding Proposition 2 (cultural capital), Namibia has long been a country of many cultures. For Whites, cultural capital may be served by libraries through the extensive fiction collections that were traditionally offered. These allowed White Namibians to read similar stories and develop their identity and culture around these tales. Black Namibians, however, because of their different tradition of library service, are more likely to expect the library to provide cultural capital in the form of support for formal education. Many Black Namibians, although not all, see education as a way to gain cultural capital and life success. Those in the library repeatedly made these claims. For example, one library user said: "Education is the key to success, to a better living standard." When pressed, she elaborated, "Education improves everything. If you are educated you even get to choose what is right and wrong."

In order to achieve this path to life success, the people using the library want libraries to have space to study, quiet and materials to help with their studies. Thus, while some of the libraries in the country still have strong fiction collections which should help build one's cultural capital among White Namibians, other libraries, particularly the newer ones, have more tables and chairs and materials to support formal education. Many Namibians believe these tools will provide them with the right cultural capital for life success.

Private libraries, such as the French Cultural Center, the Goethe Institute, and the American Cultural Center, offer access to globally applicable cultural capital. These libraries are open to all, but are only accessible to people living in Windhoek with the means to get to the center of town. These institutes also help people gain access to educational institutes in other countries.

Many people, as described above, believed that using the public libraries in Katutura and elsewhere in Namibia would help them gain educational success which would help them achieve success in life more generally. Life success did seem to be conceived more in terms of social connections, however, than in terms of educational success.

Life success did seem to be more about social connections than about educational success. Tribal affiliations and family connections were rumored to be key ways of getting jobs. Informants mentioned 
that people from the same tribe as a boss were more likely to get promoted, or that someone with a Grade 12 certification (similar to a high school diploma) received a prestigious government post over more qualified applicants because of family connections. These types of social connections did not seem to be available in the library, as suggested by Proposition 3. Many of the people using the library were in the same class, and although they kept each other motivated to study and were useful friends in the use of the library, they did not seem to be useful in gaining jobs. One of the reasons for this may have been that the public libraries are open regular business hours (generally $9 \mathrm{am}-1 \mathrm{pm}, 2-5 \mathrm{pm}$, and in some cases $9 \mathrm{am}-1 \mathrm{pm}$ on Saturdays); these hours are obviously inadequate for anyone holding a full-time job. Thus, the people in the library are more likely to be unemployed or in school, and therefore, were not people who would be a useful connection to a job.

Finally, regarding Proposition 4 (economic capital), Namibian public libraries do provide access to business resources and information about job opportunities. Job opportunities are generally listed in the newspaper, which libraries do make available. And, at least in Katutura, libraries provide patrons with the means to make their work-related documents available to potential employers, for example by providing a photocopier to copy school certificates and identification cards. Books and other resources for small businesses are available in some libraries. The Greenwell Matongo Community Library, funded by a Finnish city, has computers and computer classes to help small business owners keep track of their expenses.

\section{Nepal}

Nepal was ruled by the Rana family from 1846 until the violent uprising of 1950-51. At this time Nepal's national literacy rate was under 2 per cent, and as a consequence the country's early public libraries were little used. In order to cater to a larger segment of the population, the founders and managers organized communal educational and cultural activities. In many cases, early Nepalese libraries emerged as a common meeting ground where not only the members could have access to the reading materials, but also people from different walks of life could meet and discuss issues pertaining to their society.
With the exception of the national archive (sarkari pustakkhana) that opened to the public in 1901 (Chhetri 2005), no library was established in Nepal until Shri Gorkha Sharada Bhavan Pustakalaya was established in 1915 in the Siraha district of the Terai region. This was arguably Nepal's first public library in the modern sense of the term. It was part of the Chandramanik Pathshala (school) established by swami (ascetic) Damodarananda with the permission of prime minister Chandra Shamsher Rana. It was open in the evenings and was accessible to all Nepalis, including students. However, the 19011929 regime of Chandra Shamsher was infamous for its brutality, and the number of libraries established during this period was very small. When Bhim Shamsher Rana succeeded Chandra Shamsher, there was hope for more democracy and unnati (national progress). At the start of Bhim Shamsher's reign, the government published an istihar (advertisement/notice) in twelve languages that invited ideas and suggestions from the subjects (duniya) "in order to develop the nation." This proved to be a sham. Encouraged by the istihar, a group of local Kathmandu youths decided to open a public library in Kathmandu. They submitted a petition and began making arrangements to establish the library. But soon afterwards, nearly 50 youths who had signed the petition were arrested and charged with sedition. Some were jailed, two had to pay large fines, and the rest were released after signing a document in which they foreswore social work of any kind (Regmi 1998/99, 60; Poudel 1998/99; Chhetri 2002/ 2003; Sharma 2005/2006). This event in 1930 is known popularly as the "library incident."

From the reign of Chandra Shamsher until 1945, only one library was established in Nepal. But in the late 1940s the Indian nationalist independence movement was at its zenith, and Nepal's prime minister from 1947-48, Padma Shamsher, appeared to be receptive to social reform. However, Padma Shamsher was forced to vacate his post, paving the way for his more conservative cousin, Mohan Shamsher (194851). Of the nearly 20 libraries opened before 1951 in places like Nepalgunj, Kathmandu, Butwal, Baglung, and Dhankuta, only a handful were established during Mohan Shamsher's reign. During this period the library of Sarlahi was seized, and those involved in the library were imprisoned (Upadhyaya 1998/99). The Dhaval Library of Palpa was also closed (Nirakar 1998/99). 
In the years following the Nepalese "revolution" of 1950-51, even as the political system was in shambles, Nepalis did enjoy certain civic and political rights. These included such fundamental rights as freedom of expression and the right to dissent, which were not available to them in pre-1951 Nepal (Panday 1999). The opening up of this democratic space gave rise to new social formations: associations, political parties, educational institutions, newspapers, and new ideologies - and the ideas of modern public education and the modern public library (Regmi 1998/99, 67).

There is no agreement as to the number of libraries established by 1960 in Nepal, but a safe estimate is that there were more than 120. Regmi estimates the total number by that year to be around 125 . According to Purna Prasad Amatya, head librarian of the College of Education, there already were some two hundred public libraries opened by 1957 (Amatya 1957, 178). The 1961 report of the Overall National Education Committee lists 122 (Nepal Ministry of Education 1961, 122). According to Reed and Reed (1968), in 1960 there were 18 national and university libraries with a total of 42,000 volumes and 146 public libraries with a total of 153,000 volumes and 10,000 members.

Regarding propositions $1 \mathrm{a}$ and $1 \mathrm{~b}$, the libraries opened during the "democratic decade" of the 1950s stand out starkly from their predecessors, particularly in terms of their names. A range of types of names were in use, but the majority of them reflected the optimistic zeitgeist - the sense in the nation of progress, of moving out of darkness, and of growing national self-awareness. Nepal experienced another revolution in 2008 (Lecomte-Tilouine 2008). Today there are over 600 public libraries in the country. However, there are vast differences between the materials available in public versus private libraries in Nepal (Proposition 2, cultural capital). The private libraries (such as those that are part of private secondary schools) are much better equipped in terms of having computers and Internet access. They also have desks and chairs where young readers can comfortably spend hours reading books. The books available today in the Nepal National Library, which is the public library in Nepal with the largest budget, are very old and mostly in Nepali. There are also collections of ancient texts, but there are only four or five computers with Internet access, and members of the public must receive permission be- fore they can use them. The library also does not have a modern database system for its collections. Libraries established by NGOs such as Room to Read [4] are generally much better in terms of the basic infrastructure as well as in terms of the relevance of reading materials. Since Room to Read targets children, reading materials include books and magazines most appropriate for them and most materials are also current and up to date.

Regarding Proposition 3 (social capital), many of Nepal's public libraries are open 10:00 a.m.-5:00 p.m., but some in remote areas are open for only two or three hours daily, on weekends or evenings. Most of the public libraries have uncomfortable seating, and are inadequately heated. It might be possible for people to hold meetings or create social ties in these libraries, but patrons generally treat Nepal's libraries as places where they should keep silent and read their books. Because of space limitations, libraries do not have separate sections where people might socialize freely and discuss political issues.

Regarding Proposition 4 (economic capital), public libraries in Nepal generally do not provide access to business resources and information about job opportunities. They serve mainly educational purposes, and those to only a limited extent. They do organize library training programs, but only to recruit employees for the library itself. They do not provide information about job opportunities, as in Nepal the best source of information about jobs is newspapers, which are relatively affordable.

\section{Malawi}

Malawi is a land-locked country in the southeastern corner of sub-Saharan Africa. Although geographically small, with a population of roughly 14 million it is one of the more densely populated countries on the continent. Like most African nations, Malawi has become increasingly urban in recent decades. The vast majority of Malawians continue to reside in rural areas, however, where the main source of livelihood remains subsistence agriculture. Malawi's main roads connecting major cities and townships are in relatively good condition, but in rural areas several roads become impassable during Malawi's rainy season, restricting most Malawians' movement, or at least lengthening transport time greatly.

Public libraries were never on the forefront of the British colonial agenda. The same was true for mis- 
sionary groups who had been in Malawi prior to colonialists. The three predominant missionary groups the Universities Mission to Central Africa (UMCA), the United Free Church of Scotland Mission (or the Livingstonia Mission), and the Church of Scotland Mission (or the Blantyre Mission) - established reading rooms for themselves, but these were never public (Msiska 1998, 193). Two exceptions include the library built by Horace Waller (of the Blantyre Mission), in the now commercial capital city of Blantyre, in 1894, and the Zomba Administration Library built by Dr. Wadsworth Poole one year later (Msiska 1998, 194). Both libraries were established explicitly for British colonialists and missionaries, though, and not for Africans. In 1911, the Waller Library was made available formally to Africans, when it was given over to local authorities in Blantyre and became known as the "Blantyre Public Subscription Library." Its fees and high rates of illiteracy meant Africans were effectively excluded from the Library (Ngaunje 2003).

In 1951, the British Council established a free public library, and extended this service to branches in Zomba in 1961 and in Lilongwe in 1962. Membership requirements included a minimum of six years of education, which, like the National Subscription Library, effectively led to the exclusion of Africans, confirming that the libraries were intended for the white colonialists. Eventually, these branches were given to the National Library Service (NLS). The NLS was established in 1967 in Blantyre under an Act of Parliament (No. 31), as part of newly-independent Malawi's project of nationalization. The Malawi NLS was the first public library to offer free membership to Malawians. The Subscription Library had a difficult time competing against the National Library Service, and officially closed on March 31, 1972. (Ngaunje 2003, 197). The year of its establishment, in 1967, eleven library assistants from the British Council, the Malawi Broadcasting Corporation, and the newly formed University of Malawi attended a new Library Association Entrance Exam Course at the University of Malawi. Nine of these eleven passed, and went on to study librarianship in 1968 and 1969 in Britain. In 1976, the Malawi Library Association was formed, and today runs the Malawi Library Association Assistants" Certificate Course (Ngaunje 2003).

In 1979 NLS Library Centre operations were moved from the central government to the regional and district level. Today, the NLS operates a total of twelve "service point" branches in three regions of the country. These service points provide lending services to approximately 1,000 smaller community libraries located in schools, community centers, or orphanages. The NLS's stated goal is to focus on the "promotion of the reading culture," but the NLS provides textbooks to primary and secondary schools, and vocational resources (such as booklets) to clubs and agricultural development centers (Msiska 1998). The NLS also provides some professional and vocational books to its public libraries, as well as books, periodicals, and some reference materials on Malawi or on Nyasaland (the country's colonial name). Library Centers are loaned collections of between 200-500 books, delivered and exchanged every three months by the NLS staff. Library centres are loaned collections of between 200-500 books, delivered and exchanged every three months by the NLS staff. The centers are run by local authorities. Book donations primarily come from Book AID International.

In 2005, the NLS began to redirect some of its attention to bridging the "digital divide" between the global South and North, and established the Malawi Library and Information Consortium (MALICO). The core feature of MALICO's mission is to improve access to electronic information. MALICO operates at the organizational level - its current members are primarily the University of Malawi's Colleges, and government agencies such as the National AIDS Commission and National Reserve Bank of Malawi.

The French Cultural Centre in Blantyre houses a library in that city. The mission of the Centre is to provide a place for cultural exchange, which it does by providing French lessons and hosting events such concerts and poetry, gastronomy, and sporting events. The Centre also claims to serve as an "educational tool for Malawians." As such, the library has a small collection of books and magazines, requiring an annual membership fee of K300 for Malawians, or $\mathrm{K} 1,000$ for non-Malawians (currently, approximately $200 \mathrm{Kwacha}=1$ euro). The library is open six days a week, during the morning hours (9:00 a.m.-1:00 p.m.), and for one afternoon hour (4:00-5:00 p.m.).

Finally, the John F. Kennedy Memorial Information Resource Centre is based in the American Embassy in Lilongwe [6]. Membership is free and open to government officials, business people, academics, clergy, and the general public. Members are re- 
quired to be residents of Malawi. The Centre has a reference collection with 500 volumes, a circulation collection with approximately 4,000 books on economics, philosophy, history, government, literature, and science and technology, and a periodicals section containing 10 magazines and 39 titles of current print periodicals. The Centre is open Monday through Wednesdays, from 9:00 a.m.-3:30 p.m., and on Thursdays and Fridays from 9:00 a.m.-noon. In 2005, the American Embassy established three "American Corners" in Mzuzu in the Northern Region and Zomba and Blantyre in the South. The American Corners have approximately five computers with Internet access, are open to the public and require a small fee for Internet access. Some reference material on higher education in the U.S. is available at the American Corners, such as TOEFL, SAT, GRE, GMAT etc. Each Corner is open five days a week, from 8:00 a.m.-noon, and from 1:00 p.m.-5:00 p.m.

During the first 30 years following the 1964 independence from Britain, Malawi was ruled by the autocratic, self-named "President-for-Life" Hastings Kamuzu Banda. Upon holding its first multiparty elections in 1994, which effectively ended Banda's tenure, Malawi's new democracy emerged as a hotspot for international research projects, global civil society, and NGO activity. NGOs of various types have both flourished and floundered since 1994, but generally, the number of NGOs operating in the country since its first elections has grown. In 1993, the number of registered NGOs was 15; by 2004 , the number had climbed to 119 (Morfit 2011). One such NGO, the non-profit Invest in Knowledge Initiative (IKI), built and maintained a successful library from 2005-2010 in Mchinji, a rural district in the Central Region of the country, one hour's drive west from the capital of Lilongwe. The library is on the grounds of the Kayesa Inn, a small inn of 20 rooms established by a Dutch expatriate farmer and his Malawian wife. The Kayesa Inn is located on the main road that runs from Lilongwe to Zambia and is located 10 miles from the Zambia border. In 2010, IKI passed the management responsibility of the library onto the community. Currently, the IKI library houses more than 1,500 books and magazines, mostly donated from U.S.-based church groups, universities, middle schools, and high schools, and others donated from friends and families of IKI's co-founders. Between 2008 and 2010, the library provided two daily Malawian national newspapers, paid for by IKI. One full-time, Malawian male in his mid-20s with a secondary school degree was employed by IKI to manage the library collection and checkout system. The library is open daily from 10:00 a.m.5:00 p.m. The library is open to the public, and is used regularly by students from a neighboring public secondary school as well as by community members. Owing to a significant interest among library users, a member registration system was developed to allow users to check books out. More than 200 members have registered, permitting the removal of books from the library premises for a period of up to four weeks. Nonetheless, people from the surrounding community often use the public space of the library. The seating area includes five reading tables and twenty chairs, and people use the space to read, to practice writing, or for other events such as singing, dancing, or simply socializing.

Regarding Propositions 1a and 1b, the Malawian public library system expanded mainly during the period of authoritarian rule under Hastings Kamuzu Banda that immediately followed independence, rather than during the period of democratic rule that followed after 1994, when NGOs and foreign aid were focused mainly on AIDS and human rights issues. Banda was an autocrat, but a modernizing one who promoted the creation of the National Library Service. However, in the 1990s when Malawi became a new democracy, a number of additional, non-governmental libraries opened precisely because Malawi newly allowed NGO activity and with it their foreign aid. The question of whether better services were provided under Banda is up for debate. Banda did manage to provide some public goods and services for people in Malawi during his tenure, through, for example, the development of decent primary roads connecting major cities and towns. However, Malawi, like many developing countries, suffered an economic downturn during the 1980s following the IMF and World Bank's structural adjustment programs, during which time Banda was still in power. Prior to mass protests in July 2011, $40 \%$ of Malawi's entire budget came from foreign aid, which provides many services to Malawians.

Regarding Proposition 2 (cultural capital), it is clear that even the holdings of Malawi's best public library, the John F. Kennedy Memorial Information Resource Centre, are nowhere near the level of the holdings of the country's best private library, the 
Table 2. Public libraries and democratization.

\begin{tabular}{lllc}
\hline & Namibia & Malawi & Nepal \\
\hline Proposition 1a (expansion during democratic regimes) & $\mathrm{Y}$ & $\mathrm{N}$ & $\mathrm{Y}$ \\
Proposition 1b (democratic process) & $\mathrm{M}$ & $\mathrm{N}$ & $\mathrm{N}$ \\
Proposition 2 (cultural capital) & $\mathrm{N}$ & $\mathrm{N}$ & $\mathrm{N}[8]$ \\
Proposition 3 (social capital) & $\mathrm{N}$ & $\mathrm{N}$ \\
Proposition 4 (economic capital) & $\mathrm{Y}$ & $\mathrm{N}$ \\
\hline
\end{tabular}

Kamuzu Academy Library [7], which is part of an exclusive private high school. Where the Kennedy library has a collection of approximately 4,000 volumes and is open Monday-Wednesday 9:00 a.m.4:30 p.m., Thursday and Friday 9:00 a.m.-noon, and is closed on weekends and holidays, the Kamuzu Academy Library has approximately 26,000 volumes and is open 7:30 a.m. to either 5:30 p.m. or 9:30 p.m. every day. Regarding Proposition 3 (social capital), with the exception of the Kennedy library, Malawian public libraries are too small to offer room for spontaneous social interaction, which is uncommon in Malawian libraries in any case. Finally, while the Kennedy library makes available Malawi's two main daily newspapers The Nation and The Daily News, which do contain classified ads (mostly for INGO jobs), the country's other libraries and reading rooms do not provide informational resources for small businesses or job-seekers.

\section{Comparing the cases}

Table 2 presents a rough summary of our three case studies in terms of our four propositions. Overall, there are more negative than positive cases. Starting with Proposition 1a, in two of the three cases (Namibia and Nepal), the public library systems did expand following democratic transitions. But there are important points to consider when evaluating what appears to be a positive impact of democratization on libraries. First, the expansion of these countries' library systems occurred mainly because the newly democratic countries opened themselves to external influence from their diasporas and from INGOs. For example, after independence, members of the Nepali diaspora in India contributed heavily to Nepal's public library system. And INGOs contributed to the development of public library systems in all three countries post-independence. A second point to consider is that the contribution of democratization to public library system development seems to peter out before libraries can meaningfully contribute to democratic participation (at least according to our relatively strict criteria derived from social capital theory). Regarding Proposition 1b, none of the three countries appears to have invested in public libraries as a result of a deliberative democratic process. And regarding the three propositions derived from social capital theory (Propositions 24), there is little evidence that public libraries in any of the three countries generate or distribute significant amounts of cultural, social, or economic capital to non-elites.

\section{Conclusions}

Our exploratory comparison of the histories and current conditions of three developing countries' public library systems has significant inherent limitations. First, we have not provided precise metrics for measuring forms of capital (cultural, social, or economic) or thresholds that must be exceeded for the generation of each form of capital by a library to be considered to be contributing to democratization. Clearly, more precise operationalization of these concepts would allow for more rigorous hypothesis testing, as well as more revealing historical comparisons. Second, while we have chosen to compare three countries chosen for their similar levels of economic and human development, as with any small-N study, generalization is problematic as it is possible that had we chosen different countries we might have arrived at different conclusions. Yet despite these limitations, our findings support our contention that the ways of thinking about the relations of public libraries to democracy derived from the broad Enlightenment tradition of educational philosophy (Buschman 2007) are inadequate to the task 
of investigating the connections between libraries and democratization in a rigorous manner. Insofar as these ways of thinking dominate research on developing countries' public libraries, they invite ideology and speculation rather than social scientific inquiry.

Researchers would therefore be better off attempting to construct programs of comparative research on libraries and related cultural and educational institutions in developing countries on sounder and more contemporary theoretical edifices. Social capital theory provides one possible starting point, but there are many other potentially productive theoretical frameworks available, e.g. the work of Castells (2000) and his colleagues on the "network society." Yet a social capital approach may generate insights with significant implications for library research as well as for development theory and policy, if such an approach can begin to specify the political contexts in which public libraries meaningfully contribute to democratization. Though our analysis is exploratory in nature, it does suggest that it is necessary to understand how public libraries are connected with processes of social and political change if scarce resources are to be allocated in a way that maximizes the contributions public libraries can make to human development.

\section{Notes}

1. In the literature on social capital and in the present study, the term "social capital" is used broadly, to refer to all three forms of capital identified by Bourdieu (cultural, social, and economic), as well as more narrowly, to refer to social capital in the form of social relationships only.

2. http://www.bookaid.org/cms.cgi/site/index.htm

3. http://www.lionsclubs.org/EN/index.php

4. Comitato Internazionale per lo Sviluppo dei Popoli (The International Committee for the Development of Peoples)

5. http://www.roomtoread.org/Page.aspx?pid=183

6. http://lilongwe.usembassy.gov/irc.html

7. http://www.kamuzuacademy.com/library.htm

8. Some of the libraries in Nepal established by INGOs such as Room to Read have collections that are much better than those in government libraries.

\section{References}

Amatya, P. P. 1957. "Library Services in Nepal." Education Quarterly 2: 178-182.

Andersen, A., J. B. Friis-Hansen, and L. Kajberg. 1985. Libraries and Information Centers in the Soviet Union. Copenhagen, DK: Bibliotekscentralens forlag.

Bogart, L. 1976. Premises for Propaganda: The United States Information Agency's Operating Assumptions in the Cold War. New York: Free Press.
Bourdieu, P. 1984. Distinction: A Social Critique of the Judgment of Taste. Cambridge, MA: Harvard University Press.

Bourdieu, P. 1986. "The Forms of Capital." In Handbook of Theory and Research for the Sociology of Education, edited by J. G. Richardson, 241-258. New York: Greenwood Press.

Bourdieu, P. 1999. The Weight of the World: Social Suffering in Contemporary Society. Stanford, CA: Stanford University Press.

Bourdieu, P. 2001. Masculine Domination. Stanford, CA: Stanford University Press.

Buschman, J. 2007. "Democratic Theory in Library Information Science: Toward an Emendation." Journal for the American Society of Information Science and Technology 58 (10): 1483-1496.

Büthe, T. 2002. "Taking Temporality Seriously: Modeling History and the Use of Narratives as Evidence." American Political Science Review 96 (3): 481-493.

Castells, M. 2000 The Rise of the Network Society: Volume I: The Information Age: Economy. Oxford: Blackwell.

Chang, D. 2000. "Knowledge, Culture, and Identity: American Influence on the Development of Library and Information Science in South Korea since 1945." PhD diss., University of Texas at Austin.

Chhetri, S. 2002/2003. "Vi. sa. 1986 ko pustakalya parva" [Library Incident of Vikram Era 1986]. Janapragyamanch 3: 100-109.

Chhetri, S. 2005. "Nepalma Sarvajanik Pustakalyako Avastha ra Yasko Aavasyakata" [Status of Public Libraries and their Need in Nepal]. Janapragyamanch 6: 201-15.

Crawford, J. 1997. "Leadhills Library and a Wider World." Library Review 46: 539-53.

Dain, P. 1996. "American Public Libraries and the Third Sector: Historical Reflections and Implications." Libraries and Culture 31 (1): 56-84.

Ditzion, S. 1947. Arsenals of a Democratic Culture. Chicago, IL: American Library Association

DuMont, R. R. 1977. Reform and Reaction: The Big City Public Library in American Life. Westport, CT: Greenwood Press.

Elder, R. E. 1968. The Information Machine: The United States Information Agency and American Foreign Policy. Syracuse, NY: Syracuse University Press.

Fitzpatrick, E. B. 2008. "The Public Library as Instrument of Colonialism: The Case of the Netherlands East Indies." $\mathrm{Li}$ braries and the Cultural Record 43: 270-85.

Dogra, S., and Gulati, A. 2006. "Learning Traditions and Teacher's Role: The Indian Perspective." Educational Research and Reviews 1 (6): 165-169.

Freedom House. 2001. Freedom in the World 2000-2001. New York: Freedom House.

Hall, T. 2007. "Race and Place, a Personal Account of Unequal Access." American Libraries 38 (2): 30-33.

Harper, S. A. 1997. Information for Self-reliance and Development: A Policy Framework for Libraries and Allied Information Agencies for Namibia. Windhoek, Namibia: Ministry of Basic Education and Culture, Directorate of Library and Archives Services.

Harris, M. 1973. "The Purpose of the American Public Library." Library Journal 98 (16): 2509-2511.

Harris, M. 1986. "State, Class and Cultural Reproduction: Toward a Theory of Library Service in the United States." In 
Advances in Librarianship 14, edited by Wesley Simonton, 211-252. New York: Academic Press.

Ignatow, G. 2009. "Sites of Globalization: The Social and Cultural Origins of Community Libraries." In Politics of Globalization, edited by Samir Dasgupta and Jan Nederveen Pieterse, 406-427. London: Sage.

Ignatow, G. 2011. "What Has Globalization Done to Developing Countries" Public Libraries?" International Sociology 26 (6): 746-768.

Jackaman, P. 1980. "The Company, the Common Man, and the Library: Leadhills and Wanlockhead." Library Review 29 (1): 27-32.

Jersild, A., and N. Melkadze. 2002. "The Dilemmas of Enlightenment in the Eastern Borderlands: The Theater and Library in Tbilisi." Kritika: Explorations in Russian and Eurasian History 3 (1): 27-49.

Kranich, N., ed. 2001. Libraries and Democracy: The Cornerstones of Liberty. Chicago: American Library Association.

Lecomte-Tilouine, M. 2008. Hindu Kingship, Ethnic Revival, and Maoist Rebellion in Nepal. Oxford, UK: Oxford University Press.

Lievrouw, L. A., ed. 1994. "Information Resources and Democracy: Understanding the Paradox." Journal of the American Society for Information Science 45 (6): 350-357.

McCook, K. de la Pena. 2001. "Poverty, Democracy and Public Libraries." In Libraries and Democracy: The Cornerstones of Liberty, edited by N. Kranich, 28-47. Chicago: American Library Association.

McCook, K. de la Pena. 2004. "Serving the Demands of Democracy: The Critical Role of Libraries in Ensuring the Full Civic Participation of a Diverse Population." Threshold (Winter): 22-30. Accessed January 14, 2012. http://shell.cas.usf.edu/mccook/W04-democracy.pdf

Morfit, S. 2011. "AIDS is Money: How Donor Preferences Reconfigure Local Realities.” World Development 39 (1): 64-76.

Msiska, A. W. C. 1998. "Libraries and National Development in Malawi." Information Development 14 (4): 193-197.

Nepal Ministry of Education. 1961. Sarvangin Rastriya Shikshya Samitiko Report [Report of the All-round National Education Committee]. Kathmandu, Nepal: Ministry of Education.

Ngaunje, M. A. 2003. Malawi, National Library Service of. In Encyclopedia of Library and Information Service 44, edited by M.A. Drake, 195-206. New York: Marcel Dekker.

Nirakar, B. 1998/1999. "Dhaval Pustakalaya: Ateetdekhi Vartamansamma" [Dhaval Library: From Past to Present]. Hamro Purushartha 26: 140-143.

Nye, J. 2004. Soft Power: The Means to Success in World Politics. New York: Perseus Books.

Olden, A. 1995. Libraries in Africa: Pioneers, Policies, Problems. Lanham, MD: The Scarecrow Press.

Panday, D. R. 1999. Nepal's Failed Development: Reflections on the Mission and the Maladies. Kathmandu: Nepal South Asia Centre.

Poudel, B. 1988/1989. "Krishna Lal Adhikari Ra Makai Parva Sambandhama" [On Krishna Lal Adhikari and Maize Incident]. In Krishna Lal Adhikari ra Makai Parva [Krishna Lal Adhikari and maize incident], edited by Bhoopahari Poudel, i-x. Kathmandu: Royal Nepal Academy.

Putnam, R. 2000. Bowling Alone: The Collapse and Revival of American Community. New York: Simon and Schuster.
Putnam, R., R. Leonardi, and R. Nanetti. 1993. Making Democracy Work: Civic Traditions in Modern Italy. Princeton, NJ: Princeton University Press.

Reed, H. B., and M. J. Reed. 1968. Nepal in Transition: Educational Innovation. Pittsburgh, PA: University of Pittsburgh Press.

Regmi, S. 1998/1999. "Nepalma Sarvajanik Pustakalya" [Public Libraries in Nepal]. Hamro Purushartha 26 (1): 59-69.

Richards, P. S. 1999. "The Soviet Overseas Information Empire and the Implications of its Disintegration." In Proceedings of the 1998 Conference on the History and Heritage of Science Information Systems, edited by M. E. Bowden, T. B. Hahn, and R. V. Williams, 201-214. Medford, NJ: Information Today for the American Society for Information Science and the Chemical Heritage Foundation.

Rosenberg, D. 1993. "Imposing Libraries: The Establishment of National Public Library Services in Africa, with Particular Reference to Kenya." Third World Libraries 4 (1): 35-44.

Saunders, F. 2006. The Cultural Cold War: The CIA and the World of Arts and Letters. New York: The New Press.

Sharma, G. 2005/2006. Nepalma shikshako itihas [History of Education in Nepal], part 1. 3rd ed. Kathmandu: Makalu Books and Stationers.

Skocpol, T., and M. Somers. 1980. "The Uses of Comparative History in Macrosocial Inquiry." Comparative Studies in Society and History 22 (2): 174-197.

Snow, N. 1998. Propaganda Inc.: Selling America's Culture to the World. New York: Seven Stories Press.

Steig, M. 1992. Public Libraries in Nazi Germany. Tuscaloosa, AL: The University of Alabama Press.

Sturges, R. P. and R. Neill. 1998. The Quiet Struggle: Information and Libraries for the People of Africa. 2nd ed. Washington, D.C.: Mansell. Accessed January 14, 2012. http://www-staff.lboro.ac.uk/ lsrps/Quiet\%20Struggle\%20EBook/The\%20Quiet $\% 20$ Struggle\%20Small\%20Version/The $\% 20$ Quiet $\% 20$ Struggle\%20PDF/The\%20Quiet\%20Struggle $\% 20$ Electronic\%20Edition\%202.pdf.

Tötemeyer, A. J., and C. Stander. 1990. The State of School Libraries/Media Centers in Namibia and the Need for Training for School Libraries/Media Centers. Windhoek: University of Namibia, Department Library and Information Science.

UNESCO. 1994. IFLA/UNESCO Public Library Manifesto 1994. Accessed September 14, 2010.

http://www.unesco.org/webworld/libraries/manifestos/libram an.html.

Upadhyaya, L. 1998/1999. "Sarlahiko pahilo pustakalaya: Aarambha ra anta" [The First Library of Sarlahi: Beginning and End]. Hamro Purushartha 26: 97-100.

Vårheim, A. 2009. "Public Libraries: Places Creating Social Capital?" Library Hi Tech 27 (3): 372-381.

World Bank. 2005. "World Development Indicators 2005." Accessed February 20, 2012. http://data.worldbank.org/products/data-books/WDI-2005.

Editorial history:

Paper received: 26 May 2011

Revised paper received: 6 September 2011

Accepted: 19 September 2011 